\title{
Does Video Gaming Have Impacts on the Brain: Evidence from a Systematic Review
}

\author{
Denilson Brilliant T. ${ }^{1, *,+}$, Rui Nouchi ${ }^{2,3,+}$ and Ryuta Kawashima ${ }^{2,4}$ \\ 1 Department of Biomedicine, Indonesia International Institute for Life Sciences (i3L), East Jakarta 13210, \\ Indonesia \\ 2 Smart Ageing Research Center (SARC), Tohoku University, Sendai 980-8575, Japan; rui@tohoku.ac.jp (R.N.); \\ ryuta@tohoku.ac.jp (R.K.) \\ 3 Department of Cognitive Health Science, Institute of Development, Aging and Cancer (IDAC), \\ Tohoku University, Sendai 980-8575, Japan \\ 4 Department of Functional Brain Imaging, Institute of Development, Aging and Cancer (IDAC), \\ Tohoku University, Sendai 980-8575, Japan \\ * Correspondence: d.brilliant@i3l.ac.id; Tel.: +62-21-29567888 \\ + D.B.T. and R.N. contributed equally to this work.
}

Received: 18 August 2019; Accepted: 23 September 2019; Published: 25 September 2019 updates

\begin{abstract}
Video gaming, the experience of playing electronic games, has shown several benefits for human health. Recently, numerous video gaming studies showed beneficial effects on cognition and the brain. A systematic review of video gaming has been published. However, the previous systematic review has several differences to this systematic review. This systematic review evaluates the beneficial effects of video gaming on neuroplasticity specifically on intervention studies. Literature research was conducted from randomized controlled trials in PubMed and Google Scholar published after 2000. A systematic review was written instead of a meta-analytic review because of variations among participants, video games, and outcomes. Nine scientific articles were eligible for the review. Overall, the eligible articles showed fair quality according to Delphi Criteria. Video gaming affects the brain structure and function depending on how the game is played. The game genres examined were $3 \mathrm{D}$ adventure, first-person shooting (FPS), puzzle, rhythm dance, and strategy. The total training durations were 16-90 h. Results of this systematic review demonstrated that video gaming can be beneficial to the brain. However, the beneficial effects vary among video game types.
\end{abstract}

Keywords: brain; neuroplasticity; video gaming

\section{Introduction}

Video gaming refers to the experience of playing electronic games, which vary from action to passive games, presenting a player with physical and mental challenges. The motivation to play video games might derive from the experience of autonomy or competing with others, which can explain why video gaming is pleasurable and addictive [1].

Video games can act as "teachers" depending on the game purpose [2]. Video gaming has varying effects depending on the game genre. For instance, an active video game can improve physical fitness [3-6], whereas social video games can improve social behavior [7-9]. The most interesting results show that playing video games can change cognition and the brain [10-13].

Earlier studies have demonstrated that playing video games can benefit cognition. Cross-sectional and longitudinal studies have demonstrated that the experience of video gaming is associated with better cognitive function, specifically in terms of visual attention and short-term memory [14], reaction time [15], and working memory [16]. Additionally, some randomized controlled studies show positive 
effects of video gaming interventions on cognition $[17,18]$. Recent meta-analytical studies have also supported the positive effects of video gaming on cognition [10-13]. These studies demonstrate that playing video games does provide cognitive benefits.

The effects of video gaming intervention are ever more widely discussed among scientists [13]. A review of the results and methodological quality of recently published intervention studies must be done. One systematic review of video gaming and neural correlates has been reported [19]. However, the technique of neuroimaging of the reviewed studies was not specific. This systematic review reviewed only magnetic resonance imaging (MRI) studies in contrast to the previous systematic review to focus on neuroplasticity effect. Neuroplasticity is capability of the brain that accommodates adaptation for learning, memorizing, and recovery purposes [19]. In normal adaptation, the brain is adapting to learn, remember, forget, and repair itself. Recent studies using MRI for brain imaging techniques have demonstrated neuroplasticity effects after an intervention, which include cognitive, exercise, and music training on the grey matter [20-24] and white matter [25-29]. However, the molecular mechanisms of the grey and white matter change remain inconclusive. The proposed mechanisms for the grey matter change are neurogenesis, gliogenesis, synaptogenesis, and angiogenesis, whereas those for white matter change are myelin modeling and formation, fiber organization, and angiogenesis [30]. Recent studies using MRI technique for brain imaging have demonstrated video gaming effects on neuroplasticity. Earlier imaging studies using cross-sectional and longitudinal methods have shown that playing video games affects the brain structure by changing the grey matter [31-33], white matter [34,35], and functional connectivity [36-39]. Additionally, a few intervention studies have demonstrated that playing video games changed brain structure and functions [40-43].

The earlier review also found a link between neural correlates of video gaming and cognitive function [19]. However, that review used both experimental and correlational studies and included non-healthy participants, which contrasts to this review. The differences between this and the previous review are presented in Table 1. This review assesses only experimental studies conducted of healthy participants. Additionally, the cross-sectional and longitudinal studies merely showed an association between video gaming experiences and the brain, showing direct effects of playing video games in the brain is difficult. Therefore, this systematic review specifically examined intervention studies. This review is more specific as it reviews intervention and MRI studies on healthy participants. The purposes of this systematic review are therefore to evaluate the beneficial effects of video gaming and to assess the methodological quality of recent video gaming intervention studies.

Table 1. Differences between previous review and current review.

\begin{tabular}{ccc}
\hline Difference & Previous Review & Current Review \\
\hline Type of reviewed studies & Experimental and correlational studies & Experimental studies only \\
Neuroimaging technique of & CT, fMRI, MEG, MRI, PET, SPECT, \\
reviewed studies & tDCS, EEG, and NIRS & fMRI and MRI only \\
Participants of reviewed studies & Healthy and addicted participant & Healthy participants Only \\
\hline $\begin{array}{l}\text { CT, computed tomography; fMRI, functional magnetic resonance imaging; MEG, magnetoencephalography } \\
\text { MRI, magnetic resonance imaging; PET, positron emission tomography; SPECT, single photon emission } \\
\text { computed tomography; tDCS, transcranial direct current stimulation; EEG, electroencephalography; NIRS, } \\
\text { near-infrared spectroscopy. }\end{array}$
\end{tabular}

\section{Materials and Methods}

\subsection{Search Strategy}

This systematic review was designed in accordance with the PRISMA checklist [44] shown in Appendix A Table A1. A literature search was conducted using PubMed and Google Scholar to identify relevant studies. The keywords used for the literature search were combinations of "video game", "video gaming", "game", "action video game", "video game training", "training", "play", "playing", "MRI", "cognitive", "cognition", "executive function", and "randomized control trial". 


\subsection{Inclusion and Exclusion Criteria}

The primary inclusion criteria were randomized controlled trial study, video game interaction, and MRI/fMRI analysis. Studies that qualified with only one or two primary inclusions were not included. Review papers and experimental protocols were also not included. The secondary inclusion criteria were publishing after 2000 and published in English. Excluded were duration of less than 4 weeks or unspecified length intervention or combination intervention. Also excluded were studies of cognition-based games, and studies of participants with psychiatric, cognitive, neurological, and medical disorders.

\subsection{Quality Assessment}

Each of the quality studies was assessed using Delphi criteria [45] with several additional elements [46]: details of allocation methods, adequate descriptions of control and training groups, statistical comparisons between control and training groups, and dropout reports. The respective total scores $(\max =12)$ are shown in Table 3 . The quality assessment also includes assessment for risk of bias, which is shown in criteria numbers $1,2,5,6,7,9$, and 12 .

\subsection{Statistical Analysis}

Instead of a meta-analysis study, a systematic review of the video game training/video gaming and the effects was conducted because of the variation in ranges of participant age, video game genre, control type, MRI and statistical analysis, and training outcomes. Therefore, the quality, inclusion and exclusion, control, treatment, game title, participants, training period, and MRI analysis and specification of the studies were recorded for the respective games.

\section{Results}

The literature search made of the databases yielded 140 scientific articles. All scientific articles were screened based on inclusion and exclusion criteria. Of those 140 scientific articles, nine were eligible for the review [40-43,47-51]. Video gaming effects are listed in Table 2.

We excluded 121 articles: 46 were not MRI studies, 16 were not controlled studies, 38 were not intervention studies, 13 were review articles, and eight were miscellaneous, including study protocols, non-video gaming studies, and non-brain studies. Of 18 included scientific articles, nine were excluded. Of those nine excluded articles, two were cognitive-based game studies, three were shorter than 4 weeks in duration or were without a specified length intervention, two studies used a non-healthy participant treatment, and one was a combination intervention study. A screening flowchart is portrayed in Figure 1.

\subsection{Quality Assessment}

The assessment methodology based on Delphi criteria [45] for the quality of eligible studies is presented in Table 3. The quality scores assigned to the studies were 3-9 (mean = 6.10; S.D. $=$ 1.69). Overall, the studies showed fair methodological quality according to the Delphi criteria. The highest quality score of the nine eligible articles was assigned to "Playing Super Mario 64 increases hippocampal grey matter in older adult" published by West et al. in 2017, which scored 9 of 12. The scores assigned for criteria 6 (blinded care provider) and 7 (blinded patient) were lowest because of unspecified information related to blinding for those criteria. Additionally, criteria 2 (concealed allocation) and 5 (blinding assessor) were low because only two articles specified that information. All articles met criteria 3 and 4 adequately. 
Table 2. Summary of beneficial effect of video gaming.

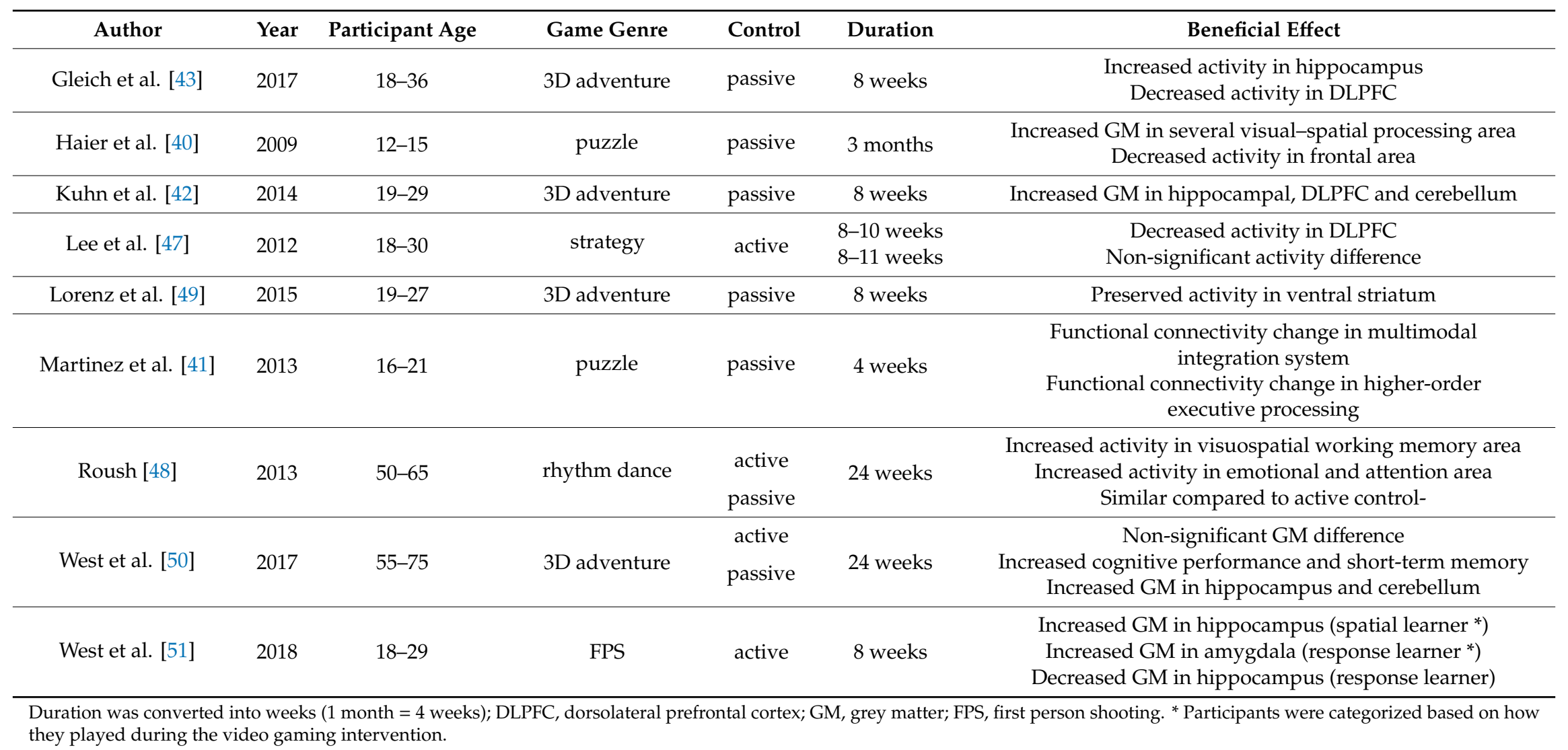

they played during the video gaming intervention. 


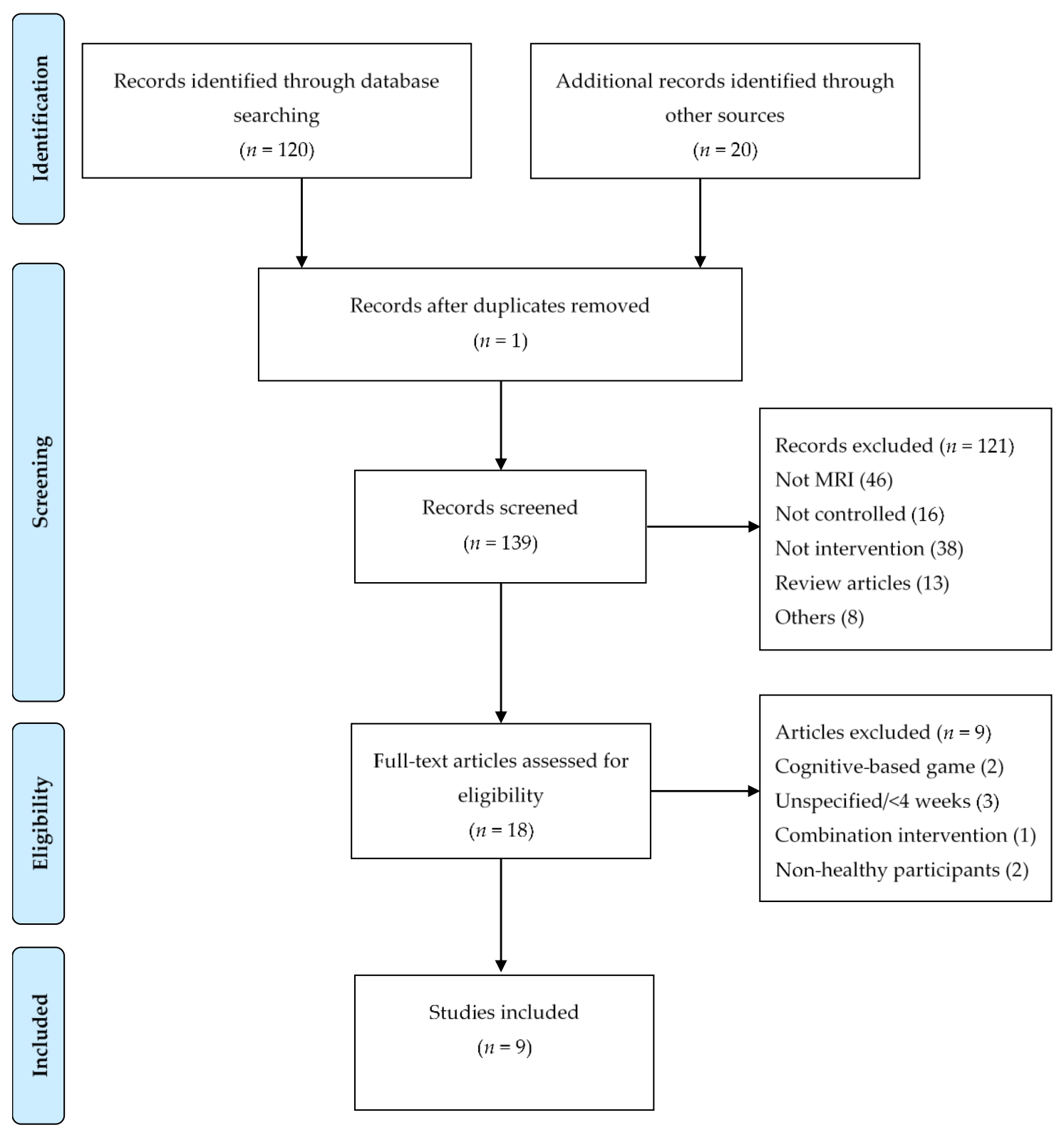

Figure 1. Flowchart of literature search.

Table 3. Methodological quality of eligible studies.

\begin{tabular}{lcccccccccccccc}
\hline \multicolumn{1}{c}{ Author } & Year & Q1 & Q2 & Q3 & Q4 & Q5 & Q6 & Q7 & Q8 & Q9 & Q10 & Q11 & Q12 & Score \\
\hline Gleich et al. [43] & 2017 & 1 & 0 & 1 & 1 & 0 & 0 & 0 & 0 & 0 & 1 & 1 & 1 & 6 \\
Haier et al. [40] & 2009 & 1 & 0 & 1 & 1 & 0 & 0 & 0 & 0 & 0 & 1 & 1 & 0 & 5 \\
Kuhn et al. [42] & 2014 & 1 & 0 & 1 & 1 & 0 & 0 & 0 & 0 & 0 & 1 & 1 & 0 & 5 \\
Lee et al. [47] & 2012 & 0 & 0 & 1 & 1 & 0 & 0 & 0 & 0 & 1 & 1 & 1 & 1 & 6 \\
Lorenz et al. [49] & 2015 & 1 & 0 & 1 & 1 & 0 & 0 & 0 & 1 & 0 & 1 & 1 & 1 & 7 \\
Martinez et al. [41] & 2013 & 0 & 0 & 1 & 1 & 0 & 0 & 0 & 0 & 0 & 0 & 1 & 0 & 3 \\
Roush [48] & 2013 & 1 & 1 & 1 & 1 & 1 & 0 & 0 & 0 & 1 & 1 & 0 & 0 & 7 \\
West et al. [50] & 2017 & 1 & 1 & 1 & 1 & 0 & 0 & 0 & 1 & 1 & 1 & 1 & 1 & 9 \\
West et al. [51] & 2018 & 0 & 0 & 1 & 1 & 1 & 0 & 0 & 1 & 1 & 1 & 0 & 1 & 7 \\
Score & & 6 & 2 & 9 & 9 & 2 & 0 & 0 & 3 & 4 & 8 & 7 & 5 & \\
\hline
\end{tabular}

Q1, Random allocation; Q2, Concealed allocation; Q3, Similar baselines among groups; Q4, Eligibility specified; Q5, Blinded assessor outcome; Q6, Blinded care provider; Q7, Blinded patient; Q8, Intention-to-treat analysis; Q9, Detail of allocation method; Q10, Adequate description of each group; Q11, Statistical comparison between groups; Q12, Dropout report (1, specified; 0 , unspecified). 


\subsection{Inclusion and Exclusion}

Most studies included participants with little or no experience with gaming and excluded participants with psychiatric/mental, neurological, and medical illness. Four studies specified handedness of the participants and excluded participants with game training experience. The inclusion and exclusion criteria are presented in Table 4.

Table 4. Inclusion and exclusion criteria for eligible studies.

\begin{tabular}{cccccccccc}
\hline \multirow{2}{*}{ Author } & \multirow{3}{*}{ Year } & \multicolumn{3}{c}{ Inclusion } & \multicolumn{5}{c}{ Exclusion } \\
\cline { 3 - 10 } & & i1 & i2 & i3 & e1 & e2 & e3 & e4 & e5 \\
\hline Gleich et al. [43] & 2017 & 1 & 0 & 0 & 1 & 1 & 1 & 1 & 1 \\
Haier et al. [40] & 2009 & 1 & 0 & 1 & 1 & 1 & 1 & 0 & 0 \\
Kuhn et al. [42] & 2014 & 1 & 0 & 0 & 1 & 1 & 1 & 1 & 1 \\
Lee et al. [47] & 2012 & 1 & 1 & 0 & 1 & 1 & 0 & 1 & 0 \\
Lorenz et al. [49] & 2015 & 1 & 1 & 0 & 1 & 0 & 0 & 1 & 1 \\
Martinez et al. [41] & 2013 & 1 & 1 & 1 & 1 & 1 & 0 & 0 & 1 \\
Roush [48] & 2013 & 0 & 0 & 1 & 0 & 0 & 1 & 0 & 0 \\
West et al. [50] & 2017 & 1 & 1 & 0 & 1 & 1 & 1 & 1 & 0 \\
West et al. [51] & 2018 & 1 & 0 & 0 & 1 & 1 & 1 & 0 & 0 \\
total & & 8 & 4 & 3 & 8 & 7 & 6 & 5 & 4
\end{tabular}

i1, Little/no experience in video gaming; i2, Right-handed; i3, Sex-specific; e1, Psychiatric/mental illness; e2, Neurological illness; e3, Medical illness; e4, MRI contraindication; e5, experience in game training.

\subsection{Control Group}

Nine eligible studies were categorized as three types based on the control type. Two studies used active control, five studies used passive control, and two studies used both active and passive control. A summary of the control group is presented in Table 5.

Table 5. Control group examined eligible studies.

\begin{tabular}{ccc}
\hline Control & Author & Year \\
\hline \multirow{2}{*}{ Active control } & Lee et al. [47] & 2012 \\
& West et al. [51] & 2018 \\
\hline \multirow{3}{*}{ Passive control } & Gleich et al. [43] & 2017 \\
& Haier et al. [40] & 2009 \\
& Kuhn et al. [42] & 2014 \\
& Lorenz et al. [49] & 2015 \\
& Martinez et al. [41] & 2013 \\
\hline \multirow{2}{*}{ Active-passive control } & Roush [48] & 2013 \\
& West et al. [50] & 2017 \\
\hline
\end{tabular}

\subsection{Game Title and Genre}

Of the nine eligible studies, four used the same 3D adventure game with different game platforms, which were "Super Mario 64" original and the DS version. One study used first-person shooting (FPS) shooting games with many different game titles: "Call of Duty" is one title. Two studies used puzzle games: "Tetris" and "Professor Layton and The Pandora's Box." One study used a rhythm dance game: Dance Revolution. One study used a strategy game: "Space Fortress." Game genres are presented in Table 6. 
Table 6. Genres and game titles of video gaming intervention.

\begin{tabular}{cccc}
\hline Genre & Author & Year & Title \\
\hline \multirow{3}{*}{ 3D adventure } & Gleich et al. [43] & 2017 & Super Mario 64 DS \\
& Kuhn et al. [42] & 2014 & Super Mario 64 \\
& Lorenz et al. [49] & 2015 & Super Mario 64 DS \\
& West et al. [50] & 2017 & Cuper Mario 64 \\
\hline FPS & West et al. * [51] & 2018 & Tetris \\
Puzzle & Haier et al. [40] & 2009 & Professor Layton and The Pandora's Box \\
\hline Rhythm dance & Martinez et al. [41] & 2013 & Dance Revolution \\
\hline Strategy & Roush [48] & 2013 & Space Fortress \\
\hline
\end{tabular}

* West et al. used multiple games; other games are Call of Duty 2, 3, Black Ops, and World at War, Killzone 2 and 3, Battlefield 2, 3, and 4, Resistance 2 and Fall of Man, and Medal of Honor.

\subsection{Participants and Sample Size}

Among the nine studies, one study examined teenage participants, six studies included young adult participants, and two studies assessed older adult participants. Participant information is shown in Table 7. Numbers of participants were 20-75 participants (mean $=43.67 ;$ S.D. $=15.63$ ). Three studies examined female-only participants, whereas six others used male and female participants. Six studies with female and male participants had more female than male participants.

\subsection{Training Period and Intensity}

The training period was $4-24$ weeks (mean $=11.49$; S.D. $=6.88$ ). One study by Lee et al. had two length periods and total hours because the study examined video game training of two types. The total training hours were $16-90 \mathrm{~h}($ mean $=40.63$; S.D. $=26.22)$, whereas the training intensity was $1.5-10.68$ $\mathrm{h} /$ week (mean $=4.96$; S.D. $=3.00$ ). One study did not specify total training hours. Two studies did not specify the training intensity. The training periods and intensities are in Table 8.

\subsection{MRI Analysis and Specifications}

Of nine eligible studies, one study used resting-state MRI analysis, three studies (excluding that by Haier et al. [40]) used structural MRI analysis, and five studies used task-based MRI analysis. A study by Haier et al. used MRI analyses of two types [40]. A summary of MRI analyses is presented in Table 9. The related resting-state, structural, and task-based MRI specifications are presented in Tables 10-12 respectively. 
Table 7. Participant details of eligible studies.

\begin{tabular}{|c|c|c|c|c|c|c|c|c|c|}
\hline \multirow{2}{*}{ Category } & \multirow{2}{*}{ Author } & \multirow{2}{*}{ Year } & \multicolumn{3}{|c|}{ Age } & \multirow{2}{*}{ Sample Size } & \multicolumn{2}{|c|}{ Ratio (\%) } & \multirow{2}{*}{ Detail } \\
\hline & & & Lowest & Highest & Range & & Female & Male & \\
\hline Teenager & Haier et al. [40] & 2009 & 12 & 15 & 3 & 44 & 70.45 & 29.54 & $\begin{array}{l}\text { Training }(n=24) \\
\text { Control }(n=20)\end{array}$ \\
\hline \multirow{6}{*}{ Young adult } & Gleich et al. [43] & 2017 & 18 & 36 & 18 & 26 & 100 & 0 & $\begin{array}{l}\text { Training }(n=15) \\
\text { Control }(n=11)\end{array}$ \\
\hline & Kuhn et al. [42] & 2014 & 19 & 29 & 10 & 48 & 70.8 & 29.2 & $\begin{array}{l}\text { Training }(n=23) \\
\text { Control }(n=25)\end{array}$ \\
\hline & Lee et al. [47] & 2012 & 18 & 30 & 12 & 75 & 61.4 & 38.6 & $\begin{array}{l}\text { Training A }(n=25) \\
\text { Training B }(n=25) \\
\text { Control }(n=25)\end{array}$ \\
\hline & Lorenz et al. [49] & 2015 & 19 & 27 & 8 & 50 & 72 & 28 & $\begin{array}{l}\text { Training }(n=25 \\
\text { Control }(n=25)\end{array}$ \\
\hline & Martinez et al. [41] & 2013 & 16 & 21 & 5 & 20 & 100 & 0 & $\begin{array}{l}\text { Training }(n=10) \\
\text { Control }(n=10)\end{array}$ \\
\hline & West et al. [51] & 2018 & 18 & 29 & 11 & 43 & 67.4 & 32.5 & $\begin{array}{c}\text { Action game }(n=21) \\
\text { Non-action game }(n=22)\end{array}$ \\
\hline \multirow{2}{*}{ Older adult } & Roush [48] & 2013 & 50 & 65 & 15 & 39 & 100 & 0 & $\begin{array}{c}\text { Training }(n=19) \\
\text { Active control }(n=15) \\
\text { Passive control }(n=5)\end{array}$ \\
\hline & West et al. [50] & 2017 & 55 & 75 & 20 & 48 & 66.7 & 33.3 & $\begin{array}{c}\text { Training }(n=19) \\
\text { Active control }(n=14) \\
\text { Passive control }(n=15)\end{array}$ \\
\hline
\end{tabular}


Table 8. Periods and intensities of video gaming intervention.

\begin{tabular}{ccccc}
\hline Author & Year & Length (Week) & Total Hours & Average Intensity (h/Week) \\
\hline Gleich et al. [43] & 2017 & 8 & 49.5 & 6.2 \\
Haier et al. [40] & 2009 & 12 & 18 & 1.5 \\
Kuhn et al. [42] & 2014 & 8 & 46.88 & 5.86 \\
Lorenz et al. [49] & 2012 & 8 & 28 & 3.5 \\
Lee et al. [47] & 2015 & $8-11 *$ & 27 & $\mathrm{n} / \mathrm{a}$ \\
Martinez et al. [41] & 2013 & 4 & 16 & 4 \\
Roush [48] & 2013 & 24 & $\mathrm{~ns}$ & $\mathrm{n} / \mathrm{a}$ \\
West et al. [50] & 2017 & 24 & 72 & 10.68 \\
West et al. [51] & 2018 & 8.4 & 90 & \\
\hline
\end{tabular}

Table 9. MRI analysis details of eligible studies.

\begin{tabular}{|c|c|c|c|c|c|c|}
\hline MRI Analysis & Author & Year & Contrast & Statistical Tool & Statistical Method & $p$ Value \\
\hline Resting & Martinez et al. [41] & 2013 & (post- $>$ pre-training $)>($ post $>$ pre-control $)$ & MATLAB; SPM8 & TFCE uncorrected & $<0.005$ \\
\hline \multirow{4}{*}{ Structural } & Haier et al. * [40] & 2009 & (post $>$ pre-training $)>($ post $>$ pre-control $)$ & MATLAB 7; SurfStat & FWE corrected & $<0.005$ \\
\hline & Kuhn et al. [42] & 2014 & $($ post $>$ pre-training $)>($ post $>$ pre-control $)$ & VBM8; SPM8 & FWE corrected & $<0.001$ \\
\hline & West et al. [50] & 2017 & $($ post $>$ pre-training $)>($ post $>$ pre-control $)$ & Bpipe & Uncorrected & $<0.0001$ \\
\hline & West et al. [51] & 2018 & $($ post $>$ pre-training $)>($ post $>$ pre-control $)$ & Bpipe & Bonferroni corrected & $<0.001$ \\
\hline \multirow{5}{*}{ Task } & Gleich et al. [43] & 2017 & (post $>$ pre-training $)>($ post $>$ pre-control $)$ & SPM12 & Monte Carlo corrected & $<0.05$ \\
\hline & Haier et al. * [40] & 2009 & (post $>$ pre-training $)>($ post $>$ pre-control $)$ & SPM7 & FDR corrected & $<0.05$ \\
\hline & Lee et al. [47] & 2012 & $($ post $>$ pre-training $)>($ post $>$ pre-control $)$ & FSL; FEAT & uncorrected & $<0.01$ \\
\hline & Lorenz et al. [49] & 2015 & $($ post $>$ pre-training $)>($ post $>$ pre-control $)$ & SPM8 & Monte Carlo corrected & $<0.05$ \\
\hline & Roush $^{+}[48]$ & 2013 & post $>$ pre-training & MATLAB 7; SPM8 & uncorrected & $=0.001$ \\
\hline
\end{tabular}

${ }^{*}$ Haier et al. conducted structural and task analyses. + Compared pre-training and post-training between groups without using contrast. TFCE, Threshold Free Cluster Enhancement; FEW, familywise error rate; FDR, false discovery rate.

Table 10. Resting-State MRI specifications of eligible studies.

\begin{tabular}{|c|c|c|c|c|c|c|c|c|c|}
\hline \multirow{2}{*}{ Author } & \multirow{2}{*}{ Year } & \multicolumn{4}{|c|}{ Resting State } & \multicolumn{4}{|c|}{ Structural } \\
\hline & & Imaging & TR (s) & TE (ms) & Slice & Imaging & TR (s) & TE (ms) & Slice \\
\hline Martinez et al. [41] & 2013 & gradient-echo planar image & 3 & 28.1 & 36 & T1-weighted & 0.92 & 4.2 & 158 \\
\hline
\end{tabular}


Table 11. Structural MRI specifications of eligible studies.

\begin{tabular}{ccccc}
\hline Author & Year & Imaging & TR (s) & TE (ms) \\
\hline Kuhn et al. [42] & 2014 & 3D T1 weighted MPRAGE & 2.5 & 4.77 \\
West et al. [50] & 2017 & 3D gradient echo MPRAGE & 2.3 & 2.91 \\
West et al. [51] & 2018 & 3D gradient echo MPRAGE & 2.3 & 2.91 \\
\hline
\end{tabular}

Table 12. Task-Based MRI specifications of eligible studies.

\begin{tabular}{|c|c|c|c|c|c|c|c|c|c|c|}
\hline \multirow{2}{*}{ Author } & \multirow{2}{*}{ Year } & \multirow{2}{*}{ Task } & \multicolumn{4}{|c|}{ BOLD } & \multicolumn{4}{|c|}{ Structural } \\
\hline & & & Imaging & TR (s) & TE (ms) & Slice & Imaging & TR (s) & TE (ms) & Slice \\
\hline Gleich et al. [43] & 2017 & win-loss paradigm & $\begin{array}{l}\text { T2 echo-planar } \\
\text { image }\end{array}$ & 2 & 30 & 36 & T1-weighted & 2.5 & 4.77 & 176 \\
\hline Haier et al. [40] & 2009 & Tetris & $\begin{array}{l}\text { Functional echo } \\
\text { planar }\end{array}$ & 2 & 29 & ns & 5-echo MPRAGE & 2.53 & $\begin{array}{c}1.64 ; 3.5 ; 5.36 \\
7.22 ; 9.08\end{array}$ & ns \\
\hline Lee et al. [47] & 2012 & game control & $\begin{array}{c}\text { fast echo-planar } \\
\text { image }\end{array}$ & 2 & 25 & ns & $\begin{array}{l}\text { T1-weighted } \\
\text { MPRAGE }\end{array}$ & 1.8 & 3.87 & 144 \\
\hline Lorenz et al. [49] & 2015 & $\begin{array}{l}\text { slot machine } \\
\text { paradigm }\end{array}$ & $\begin{array}{l}\text { T2 echo-planar } \\
\text { image }\end{array}$ & 2 & 30 & 36 & $\begin{array}{l}\text { T1-weighted } \\
\text { MPRAGE }\end{array}$ & 2.5 & 4.77 & ns \\
\hline Roush [48] & 2013 & $\begin{array}{l}\text { digit symbol } \\
\text { substitution }\end{array}$ & $\begin{array}{l}\text { fast echo-planar } \\
\text { image }\end{array}$ & 2 & 25 & 34 & $\begin{array}{c}\text { diffusion } \\
\text { weighted image }\end{array}$ & ns & ns & ns \\
\hline
\end{tabular}

All analyses used 3 Tesla magnetic force; TR $=$ repetition time; TE $=$ echo time, $\mathrm{ns}=$ not specified. 


\section{Discussion}

This literature review evaluated the effect of noncognitive-based video game intervention on the cognitive function of healthy people. Comparison of studies is difficult because of the heterogeneities of participant ages, beneficial effects, and durations. Comparisons are limited to studies sharing factors.

\subsection{Participant Age}

Video gaming intervention affects all age categories except for the children category. The exception derives from a lack of intervention studies using children as participants. The underlying reason for this exception is that the brain is still developing until age 10-12 [52,53]. Among the eligible studies were a study investigating adolescents [40], six studies investigating young adults $[41-43,47,49,51]$ and two studies investigating older adults [48,50].

Differences among study purposes underlie the differences in participant age categories. The study by Haier et al. was intended to study adolescents because the category shows the most potential brain changes. The human brain is more sensitive to synaptic reorganization during the adolescent period [54]. Generally, grey matter decreases whereas white matter increases during the adolescent period $[55,56]$. By contrast, the cortical surface of the brain increases despite reduction of grey matter $[55,57]$. Six studies were investigating young adults with the intention of studying brain changes after the brain reaches maturity. The human brain reaches maturity during the young adult period [58]. Two studies were investigating older adults with the intention of combating difficulties caused by aging. The human brain shrinks as age increases [56,59], which almost invariably leads to declining cognitive function $[59,60]$.

\subsection{Beneficial Effects}

Three beneficial outcomes were observed using MRI method: grey matter change $[40,42,50]$, brain activity change [40,43,47-49], and functional connectivity change [41]. The affected brain area corresponds to how the respective games were played.

Four studies of 3D video gaming showed effects on the structure of hippocampus, dorsolateral prefrontal cortex (DLPFC), cerebellum [42,43,50], and DLPFC [43] and ventral striatum activity [49]. In this case, the hippocampus is used for memory [61] and scene recognition [62], whereas the DLPFC and cerebellum are used for working memory function for information manipulation and problem-solving processes [63]. The grey matter of the corresponding brain region has been shown to increase during training [20,64]. The increased grey matter of the hippocampus, DLPFC, and cerebellum are associated with better performance in reference and working memory $[64,65]$.

The reduced activity of DLPFC found in the study by Gleich et al. corresponds to studies that showed reduced brain activity associated with brain training [66-69]. Decreased activity of the DLPFC after training is associated with efficiency in divergent thinking [70]. 3D video gaming also preserved reward systems by protecting the activity of the ventral striatum [71].

Two studies of puzzle gaming showed effects on the structure of the visual-spatial processing area, activity of the frontal area, and functional connectivity change. The increased grey matter of the visual-spatial area and decreased activity of the frontal area are similar to training-associated grey matter increase [20,64] and activity decrease [66-69]. In this case, visual-spatial processing and frontal area are used constantly for spatial prediction and problem-solving of Tetris. Functional connectivity of the multimodal integration and the higher-order executive system in the puzzle solving-based gaming of Professor Layton game corresponds to studies which demonstrated training-associated functional connectivity change [72,73]. Good functional connectivity implies better performance [73]. 
Strategy gaming affects the DLPFC activity, whereas rhythm gaming affects the activity of visuospatial working memory, emotional, and attention area. FPS gaming affects the structure of the hippocampus and amygdala. Decreased DLPFC activity is similar to training-associated activity decrease [66-69]. A study by Roush demonstrated increased activity of visuospatial working memory, emotion, and attention area, which might occur because of exercise and gaming in the Dance Revolution game. Results suggest that positive activations indicate altered functional areas by complex exercise [48]. The increased grey matter of the hippocampus and amygdala are similar to the training-associated grey matter increase [20,64]. The hippocampus is used for 3D navigation purposes in the FPS world [61], whereas the amygdala is used to stay alert during gaming [74].

\subsection{Duration}

Change of the brain structure and function was observed after $16 \mathrm{~h}$ of video gaming. The total durations of video gaming were $16-90 \mathrm{~h}$. However, the gaming intensity must be noted because the gaming intensity varied: $1.5-10.68 \mathrm{~h}$ per week. The different intensities might affect the change of cognitive function. Cognitive intervention studies demonstrated intensity effects on the cortical thickness of the brain $[75,76]$. A similar effect might be observed in video gaming studies. More studies must be conducted to resolve how the intensity can be expected to affect cognitive function.

\subsection{Criteria}

Almost all studies used inclusion criteria "little/no experience with video games." The criterion was used to reduce the factor of gaming-related experience on the effects of video gaming. Some of the studies also used specific handedness and specific sex of participants to reduce the variation of brain effects. Expertise and sex are shown to affect brain activity and structure [77-80]. The exclusion criterion of "MRI contraindication" is used for participant safety for the MRI protocol, whereas exclusion criteria of "psychiatric/mental illness", "neurological illness", and "medical illness" are used to standardize the participants.

\subsection{Limitations and Recommendations}

Some concern might be raised about the quality of methodology, assessed using Delphi criteria [45]. The quality was 3-9 $($ mean $=6.10$; S.D. $=1.69)$. Low quality in most papers resulted from unspecified information corresponding to the criteria. Quality improvements for the studies must be performed related to the low quality of methodology. Allocation concealment, assessor blinding, care provider blinding, participant blinding, intention-to-treat analysis, and allocation method details must be improved in future studies.

Another concern is blinding and control. This type of study differs from medical studies in which patients can be blinded easily. In studies of these types, the participants were tasked to do either training as an active control group or to do nothing as a passive control group. The participants can expect something from the task. The expectation might affect the outcomes of the studies [81-83]. Additionally, the waiting-list control group might overestimate the outcome of training [84].

Considering the sample size, which was 20-75 (mean $=43.67$; S.D. $=15.63)$, the studies must be upscaled to emphasize video gaming effects. There are four phases of clinical trials that start from the early stage and small-scale phase 1 to late stage and large-scale phase 3 and end in post-marketing observation phase 4 . These four phases are used for drug clinical trials, according to the food and drug administration (FDA) [85]. Phase 1 has the purpose of revealing the safety of treatment with around 20-100 participants. Phase 2 has the purpose of elucidating the efficacy of the treatment with up to several hundred participants. Phase 3 has the purpose of revealing both efficacy and safety among 300-3000 participants. The final phase 4 has the purpose of finding unprecedented adverse effects of treatment after marketing. However, because medical studies and video gaming intervention studies differ in terms of experimental methods, slight modifications can be done for adaptation to video gaming studies. 
Several unresolved issues persist in relation to video gaming intervention. First, no studies assessed chronic/long-term video gaming. The participants might lose their motivation to play the same game over a long time, which might affect the study outcomes [86]. Second, meta-analyses could not be done because the game genres are heterogeneous. To ensure homogeneity of the study, stricter criteria must be set. However, this step would engender a third limitation. Third, randomized controlled trial video gaming studies that use MRI analysis are few. More studies must be conducted to assess the effects of video gaming. Fourth, the eligible studies lacked cognitive tests to validate the cognitive change effects for training. Studies of video gaming intervention should also include a cognitive test to ascertain the relation between cognitive function and brain change.

\section{Conclusions}

The systematic review has several conclusions related to beneficial effects of noncognitive-based video games. First, noncognitive-based video gaming can be used in all age categories as a means to improve the brain. However, effects on children remain unclear. Second, noncognitive-based video gaming affects both structural and functional aspects of the brain. Third, video gaming effects were observed after a minimum of $16 \mathrm{~h}$ of training. Fourth, some methodology criteria must be improved for better methodological quality. In conclusion, acute video gaming of a minimum of $16 \mathrm{~h}$ is beneficial for brain function and structure. However, video gaming effects on the brain area vary depending on the video game type.

Author Contributions: D.B.T., R.N., and R.K. designed the systematic review. D.B.T. and R.N. searched and selected the papers. D.B.T. and R.N. wrote the manuscript with R.K. All authors read and approved the final manuscript. D.B.T. and R.N. contributed equally to this work.

Funding: Study is supported by JSPS KAKENHI Grant Number 17H06046 (Grant-in-Aid for Scientific Research on Innovative Areas) and 16KT0002 (Grant-in-Aid for Scientific Research (B)).

Acknowledgments: We would like to thank all our other colleagues in IDAC, Tohoku University for their support.

Conflicts of Interest: None of the other authors has any conflict of interest to declare. Funding sources are not involved in the study design, collection, analysis, interpretation of data, or writing of the study report. 


\section{Appendix A}

Table A1. PRISMA Checklist of the literature review.

\begin{tabular}{|c|c|c|c|}
\hline Section/Topic & $\#$ & Checklist Item & Reported on Page \# \\
\hline \multicolumn{4}{|c|}{ TITLE } \\
\hline Title & 1 & Identify the report as a systematic review, meta-analysis, or both. & 1 \\
\hline \multicolumn{4}{|c|}{ ABSTRACT } \\
\hline Structured summary & 2 & $\begin{array}{l}\text { Provide a structured summary including, as applicable: background; objectives; data sources; study } \\
\text { eligibility criteria, participants, and interventions; study appraisal and synthesis methods; results; } \\
\text { limitations; conclusions and implications of key findings; systematic review registration number. }\end{array}$ & 1 \\
\hline \multicolumn{4}{|c|}{ INTRODUCTION } \\
\hline Rationale & 3 & Describe the rationale for the review in the context of what is already known. & 1,2 \\
\hline Objectives & 4 & $\begin{array}{l}\text { Provide an explicit statement of questions being addressed related to participants, interventions, } \\
\text { comparisons, outcomes, and study design (PICOS). }\end{array}$ & 2 \\
\hline \multicolumn{4}{|c|}{ METHODS } \\
\hline Protocol and registration & 5 & $\begin{array}{l}\text { Indicate if a review protocol exists, if and where it is accessible (e.g., Web address), and if available, } \\
\text { provide registration information including registration number. }\end{array}$ & 2 \\
\hline Eligibility criteria & 6 & $\begin{array}{l}\text { Specify study characteristics (e.g., PICOS, length of follow-up) and report characteristics (e.g., years } \\
\text { considered, language, publication status) used as criteria for eligibility, giving rationale. }\end{array}$ & 2 \\
\hline Information sources & 7 & $\begin{array}{l}\text { Describe all information sources (e.g., databases with dates of coverage, contact with study authors } \\
\text { to identify additional studies) in the search and date last searched. }\end{array}$ & 2 \\
\hline Search & 8 & $\begin{array}{l}\text { Present full electronic search strategy for at least one database, including any limits used, such that it } \\
\text { could be repeated. }\end{array}$ & 2 \\
\hline Study selection & 9 & $\begin{array}{l}\text { State the process for selecting studies (i.e., screening, eligibility, included in systematic review, and if } \\
\text { applicable, included in the meta-analysis). }\end{array}$ & 3 \\
\hline Data collection process & 10 & $\begin{array}{l}\text { Describe method of data extraction from reports (e.g., piloted forms, independently, in duplicate) } \\
\text { and any processes for obtaining and confirming data from investigators. }\end{array}$ & 3 \\
\hline Data items & 11 & $\begin{array}{c}\text { List and define all variables for which data were sought (e.g., PICOS, funding sources) and any } \\
\text { assumptions and simplifications made. }\end{array}$ & 3 \\
\hline Risk of bias in individual studies & 12 & $\begin{array}{l}\text { Describe methods used for assessing risk of bias of individual studies (including specification of } \\
\text { whether this was done at the study or outcome level), and how this information is to be used in any } \\
\text { data synthesis. }\end{array}$ & 2 \\
\hline Summary measures & 13 & State the principal summary measures (e.g., risk ratio, difference in means). & - \\
\hline
\end{tabular}


Table A1. Cont.

\begin{tabular}{|c|c|c|c|}
\hline Section/Topic & $\#$ & Checklist Item & Reported on Page \# \\
\hline Synthesis of results & 14 & $\begin{array}{l}\text { Describe the methods of handling data and combining results of studies, if done, including measures } \\
\left.\text { of consistency (e.g., } \mathrm{I}^{2}\right) \text { for each meta-analysis. }\end{array}$ & - \\
\hline Risk of bias across studies & 15 & $\begin{array}{c}\text { Specify any assessment of risk of bias that might affect the cumulative evidence (e.g., publication } \\
\text { bias, selective reporting within studies). }\end{array}$ & - \\
\hline Additional analyses & 16 & $\begin{array}{c}\text { Describe methods of additional analyses (e.g., sensitivity or subgroup analyses, meta-regression), if } \\
\text { done, indicating which were pre-specified. }\end{array}$ & - \\
\hline \multicolumn{4}{|c|}{ RESULTS } \\
\hline Study selection & 17 & $\begin{array}{l}\text { Give numbers of studies screened, assessed for eligibility, and included in the review, with reasons } \\
\text { for exclusions at each stage, ideally with a flow diagram. }\end{array}$ & 3,5 \\
\hline Study characteristics & 18 & $\begin{array}{c}\text { For each study, present characteristics for which data were extracted (e.g., study size, PICOS, } \\
\text { follow-up period) and provide the citations. }\end{array}$ & $5-11$ \\
\hline Risk of bias within studies & 19 & $\begin{array}{l}\text { Present data on risk of bias of each study, and if available, any outcome level assessment (see item } \\
\text { 12). }\end{array}$ & 5,6 \\
\hline Results of individual studies & 20 & $\begin{array}{l}\text { For all outcomes considered (benefits or harms), present, for each study: (a) simple summary data } \\
\text { for each intervention group (b) effect estimates and confidence intervals, ideally with a forest plot. }\end{array}$ & 4 \\
\hline Synthesis of results & 21 & $\begin{array}{c}\text { Present results of each meta-analysis done, including confidence intervals and measures of } \\
\text { consistency. }\end{array}$ & - \\
\hline Risk of bias across studies & 22 & Present results of any assessment of risk of bias across studies (see Item 15). & - \\
\hline \multicolumn{4}{|c|}{ DISCUSSION } \\
\hline Summary of evidence & 24 & $\begin{array}{l}\text { Summarize the main findings including the strength of evidence for each main outcome; consider } \\
\text { their relevance to key groups (e.g., healthcare providers, users, and policy makers). }\end{array}$ & 12,13 \\
\hline Limitations & 25 & $\begin{array}{l}\text { Discuss limitations at study and outcome level (e.g., risk of bias), and at review-level (e.g., } \\
\text { incomplete retrieval of identified research, reporting bias). }\end{array}$ & 13 \\
\hline Conclusions & 26 & $\begin{array}{c}\begin{array}{c}\text { Provide a general interpretation of the results in the context of other evidence, and implications for } \\
\text { future research. }\end{array}\end{array}$ & 14 \\
\hline \multicolumn{4}{|c|}{ FUNDING } \\
\hline Funding & 27 & $\begin{array}{l}\begin{array}{l}\text { Describe sources of funding for the systematic review and other support (e.g., supply of data); role of } \\
\text { funders for the systematic review. }\end{array}\end{array}$ & 14 \\
\hline
\end{tabular}




\section{References}

1. Ryan, R.M.; Rigby, C.S.; Przybylski, A. The Motivational Pull of Video Games: A Self-Determination Theory Approach. Motiv. Emot. 2006, 30, 344-360. [CrossRef]

2. Gentile, D.A.; Gentile, J.R. Violent Video Games as Exemplary Teachers: A Conceptual Analysis. J. Youth Adolesc. 2008, 37, 127-141. [CrossRef]

3. McDougall, J.; Duncan, M.J. Children, video games and physical activity: An exploratory study. Int. J. Disabil. Hum. Dev. 2008, 7, 89-94. [CrossRef]

4. Ni Mhurchu, C.; Maddison, R.; Jiang, Y.; Jull, A.; Prapavessis, H.; Rodgers, A. Couch potatoes to jumping beans: A pilot study of the effect of active video games on physical activity in children. Int. J. Behav. Nutr. Phys. Act. 2008, 5, 8. [CrossRef] [PubMed]

5. Murphy, E.C.-S.; Carson, L.; Neal, W.; Baylis, C.; Donley, D.; Yeater, R. Effects of an exercise intervention using Dance Dance Revolution on endothelial function and other risk factors in overweight children. Int. J. Pediatr. Obes. 2009, 4, 205-214. [CrossRef] [PubMed]

6. Maddison, R.; Foley, L.; Ni Mhurchu, C.; Jiang, Y.; Jull, A.; Prapavessis, H.; Hohepa, M.; Rodgers, A. Effects of active video games on body composition: A randomized controlled trial. Am. J. Clin. Nutr. 2011, 94, 156-163. [CrossRef] [PubMed]

7. Cole, H.; Griffiths, M.D. Social Interactions in Massively Multiplayer Online Role-Playing Gamers. Cyberpsychol. Behav. 2007, 10, 575-583. [CrossRef]

8. Gentile, D.A.; Anderson, C.A.; Yukawa, S.; Ihori, N.; Saleem, M.; Ming, L.K.; Shibuya, A.; Liau, A.K.; Khoo, A.; Bushman, B.J.; et al. The Effects of Prosocial Video Games on Prosocial Behaviors: International Evidence from Correlational, Longitudinal, and Experimental Studies. Pers. Soc. Psychol. Bull. 2009, 35, 752-763. [CrossRef]

9. Greitemeyer, T.; Osswald, S. Effects of prosocial video games on prosocial behavior. J. Pers. Soc. Psychol. 2010, 98, 211. [CrossRef]

10. Spence, I.; Feng, J. Video Games and Spatial Cognition. Rev. Gen. Psychol. 2010, 14, 92-104. [CrossRef]

11. Wouters, P.; van Nimwegen, C.; van Oostendorp, H.; van der Spek, E.D. A meta-analysis of the cognitive and motivational effects of serious games. J. Educ. Psychol. 2013, 105, 249. [CrossRef]

12. Toril, P.; Reales, J.M.; Ballesteros, S. Video game training enhances cognition of older adults: A meta-analytic study. Psychol. Aging 2014, 29, 706. [CrossRef] [PubMed]

13. Shams, T.A.; Foussias, G.; Zawadzki, J.A.; Marshe, V.S.; Siddiqui, I.; Müller, D.J.; Wong, A.H.C. The Effects of Video Games on Cognition and Brain Structure: Potential Implications for Neuropsychiatric Disorders. Curr. Psychiatry Rep. 2015, 17, 71. [CrossRef] [PubMed]

14. Wilms, I.L.; Petersen, A.; Vangkilde, S. Intensive video gaming improves encoding speed to visual short-term memory in young male adults. Acta Psychol. 2013, 142, 108-118. [CrossRef] [PubMed]

15. Steenbergen, L.; Sellaro, R.; Stock, A.-K.; Beste, C.; Colzato, L.S. Action Video Gaming and Cognitive Control: Playing First Person Shooter Games Is Associated with Improved Action Cascading but Not Inhibition. PLoS ONE 2015, 10, e0144364. [CrossRef] [PubMed]

16. Moisala, M.; Salmela, V.; Hietajärvi, L.; Carlson, S.; Vuontela, V.; Lonka, K.; Hakkarainen, K.; Salmela-Aro, K.; Alho, K. Gaming is related to enhanced working memory performance and task-related cortical activity. Brain Res. 2017, 1655, 204-215. [CrossRef] [PubMed]

17. Nouchi, R.; Taki, Y.; Takeuchi, H.; Hashizume, H.; Akitsuki, Y.; Shigemune, Y.; Sekiguchi, A.; Kotozaki, Y.; Tsukiura, T.; Yomogida, Y.; et al. Brain Training Game Improves Executive Functions and Processing Speed in the Elderly: A Randomized Controlled Trial. PLoS ONE 2012, 7, e29676. [CrossRef] [PubMed]

18. Nouchi, R.; Taki, Y.; Takeuchi, H.; Hashizume, H.; Nozawa, T.; Kambara, T.; Sekiguchi, A.; Miyauchi, C.M.; Kotozaki, Y.; Nouchi, H.; et al. Brain Training Game Boosts Executive Functions, Working Memory and Processing Speed in the Young Adults: A Randomized Controlled Trial. PLoS ONE 2013, 8, e55518. [CrossRef] [PubMed]

19. Palaus, M.; Marron, E.M.; Viejo-Sobera, R.; Redolar-Ripoll, D. Neural Basis of Video Gaming: A Systematic Review. Front. Hum. Neurosci. 2017, 11, 248. [CrossRef]

20. Draganski, B.; Gaser, C.; Busch, V.; Schuierer, G.; Bogdahn, U.; May, A. Changes in grey matter induced by training. Nature 2004, 427, 312. [CrossRef] 
21. Gauthier, L.V.; Taub, E.; Perkins, C.; Ortmann, M.; Mark, V.W.; Uswatte, G. Remodeling the Brain: Plastic Structural Brain Changes Produced by Different Motor Therapies After Stroke. Stroke 2008, 39, 1520. [CrossRef] [PubMed]

22. Engvig, A.; Fjell, A.M.; Westlye, L.T.; Skaane, N.V.; Dale, A.M.; Holland, D.; Due-Tønnessen, P.; Sundseth, Ø.; Walhovd, K.B. Effects of Cognitive Training on Gray Matter Volumes in Memory Clinic Patients with Subjective Memory Impairment. JAD 2014, 41, 779-791. [CrossRef] [PubMed]

23. Matura, S.; Fleckenstein, J.; Deichmann, R.; Engeroff, T.; Füzéki, E.; Hattingen, E.; Hellweg, R.; Lienerth, B.; Pilatus, U.; Schwarz, S.; et al. Effects of aerobic exercise on brain metabolism and grey matter volume in older adults: Results of the randomised controlled SMART trial. Transl. Psychiatry 2017, 7, e1172. [CrossRef] [PubMed]

24. Rehfeld, K.; Lüders, A.; Hökelmann, A.; Lessmann, V.; Kaufmann, J.; Brigadski, T.; Müller, P.; Müller, N.G. Dance training is superior to repetitive physical exercise in inducing brain plasticity in the elderly. PLoS ONE 2018, 13, e0196636. [CrossRef] [PubMed]

25. Steele, C.J.; Bailey, J.A.; Zatorre, R.J.; Penhune, V.B. Early Musical Training and White-Matter Plasticity in the Corpus Callosum: Evidence for a Sensitive Period. J. Neurosci. 2013, 33, 1282-1290. [CrossRef] [PubMed]

26. Bonzano, L.; Tacchino, A.; Brichetto, G.; Roccatagliata, L.; Dessypris, A.; Feraco, P.; Lopes De Carvalho, M.L.; Battaglia, M.A.; Mancardi, G.L.; Bove, M. Upper limb motor rehabilitation impacts white matter microstructure in multiple sclerosis. Neuroimage 2014, 90, 107-116. [CrossRef] [PubMed]

27. Engel, A.; Hijmans, B.S.; Cerliani, L.; Bangert, M.; Nanetti, L.; Keller, P.E.; Keysers, C. Inter-Individual Differences in Audio-Motor Learning of Piano Melodies and White Matter Fiber Tract Architecture: Inter-Individual Piano Learning Abilities and White Matter Tracts. Hum. Brain Mapp. 2014, 35, 2483-2497. [CrossRef] [PubMed]

28. Rasova, K.; Prochazkova, M.; Tintera, J.; Ibrahim, I.; Zimova, D.; Stetkarova, I. Motor programme activating therapy influences adaptive brain functions in multiple sclerosis: Clinical and MRI study. Int. J. Rehabilit. Res. 2015, 38, 49-54. [CrossRef] [PubMed]

29. Huber, E.; Donnelly, P.M.; Rokem, A.; Yeatman, J.D. Rapid and widespread white matter plasticity during an intensive reading intervention. Nat. Commun. 2018, 9, 2260. [CrossRef]

30. Zatorre, R.J.; Fields, R.D.; Johansen-Berg, H. Plasticity in gray and white: Neuroimaging changes in brain structure during learning. Nat. Neurosci. 2012, 15, 528. [CrossRef]

31. Kühn, S.; Romanowski, A.; Schilling, C.; Lorenz, R.; Mörsen, C.; Seiferth, N.; Banaschewski, T.; Barbot, A.; Barker, G.J.; Büchel, C.; et al. The neural basis of video gaming. Transl. Psychiatry 2011, 1, e53. [CrossRef] [PubMed]

32. Kühn, S.; Gallinat, J. Amount of lifetime video gaming is positively associated with entorhinal, hippocampal and occipital volume. Mol. Psychiatry 2014, 19, 842. [CrossRef] [PubMed]

33. Tanaka, S.; Ikeda, H.; Kasahara, K.; Kato, R.; Tsubomi, H.; Sugawara, S.K.; Mori, M.; Hanakawa, T.; Sadato, N.; Honda, M.; et al. Larger Right Posterior Parietal Volume in Action Video Game Experts: A Behavioral and Voxel-Based Morphometry (VBM) Study. PLoS ONE 2013, 8, e66998. [CrossRef] [PubMed]

34. Zhang, Y.; Du, G.; Yang, Y.; Qin, W.; Li, X.; Zhang, Q. Higher integrity of the motor and visual pathways in long-term video game players. Front. Hum. Neurosci. 2015, 9, 98. [CrossRef] [PubMed]

35. Ray, N.R.; O'Connell, M.A.; Nashiro, K.; Smith, E.T.; Qin, S.; Basak, C. Evaluating the relationship between white matter integrity, cognition, and varieties of video game learning. RNN 2017, 35, 437-456. [CrossRef]

36. Granek, J.A.; Gorbet, D.J.; Sergio, L.E. Extensive video-game experience alters cortical networks for complex visuomotor transformations. Cortex 2010, 46, 1165-1177. [CrossRef]

37. Li, R.W.; Ngo, C.; Nguyen, J.; Levi, D.M. Video-Game Play Induces Plasticity in the Visual System of Adults with Amblyopia. PLoS Biol. 2011, 9, e1001135. [CrossRef]

38. Gong, D.; He, H.; Liu, D.; Ma, W.; Dong, L.; Luo, C.; Yao, D. Enhanced functional connectivity and increased gray matter volume of insula related to action video game playing. Sci. Rep. 2015, 5, 9763. [CrossRef]

39. Wang, P.; Zhu, X.-T.; Qi, Z.; Huang, S.; Li, H.-J. Neural Basis of Enhanced Executive Function in Older Video Game Players: An fMRI Study. Front. Aging Neurosci. 2017, 9, 382. [CrossRef]

40. Haier, R.J.; Karama, S.; Leyba, L.; Jung, R.E. MRI assessment of cortical thickness and functional activity changes in adolescent girls following three months of practice on a visual-spatial task. BMC Res. Notes 2009, 2, 174. [CrossRef] 
41. Martínez, K.; Solana, A.B.; Burgaleta, M.; Hernández-Tamames, J.A.; Álvarez-Linera, J.; Román, F.J.; Alfayate, E.; Privado, J.; Escorial, S.; Quiroga, M.A.; et al. Changes in resting-state functionally connected parietofrontal networks after videogame practice: Videogame Practice and Functional Connectivity. Hum. Brain Mapp. 2013, 34, 3143-3157. [CrossRef] [PubMed]

42. Kühn, S.; Gleich, T.; Lorenz, R.C.; Lindenberger, U.; Gallinat, J. Playing Super Mario induces structural brain plasticity: Gray matter changes resulting from training with a commercial video game. Mol. Psychiatry 2014, 19, 265. [CrossRef] [PubMed]

43. Gleich, T.; Lorenz, R.C.; Gallinat, J.; Kühn, S. Functional changes in the reward circuit in response to gaming-related cues after training with a commercial video game. Neuroimage 2017, 152, 467-475. [CrossRef] [PubMed]

44. Liberati, A.; Altman, D.G.; Tetzlaff, J.; Mulrow, C.; Gøtzsche, P.C.; Ioannidis, J.P.A.; Clarke, M.; Devereaux, P.J.; Kleijnen, J.; Moher, D. The PRISMA Statement for Reporting Systematic Reviews and Meta-Analyses of Studies That Evaluate Health Care Interventions: Explanation and Elaboration. PLoS Med. 2009, 6, e1000100. [CrossRef] [PubMed]

45. Verhagen, A.P.; de Vet, H.C.W.; de Bie, R.A.; Kessels, A.G.H.; Boers, M.; Bouter, L.M.; Knipschild, P.G. The Delphi List: A Criteria List for Quality Assessment of Randomized Clinical Trials for Conducting Systematic Reviews Developed by Delphi Consensus. J. Clin. Epidemiol. 1998, 51, 1235-1241. [CrossRef]

46. Nouchi, R.; Kawashima, R. Improving Cognitive Function from Children to Old Age: A Systematic Review of Recent Smart Ageing Intervention Studies. Adv. Neurosci. 2014, 2014. [CrossRef]

47. Lee, H.; Voss, M.W.; Prakash, R.S.; Boot, W.R.; Vo, L.T.K.; Basak, C.; VanPatter, M.; Gratton, G.; Fabiani, M.; Kramer, A.F. Videogame training strategy-induced change in brain function during a complex visuomotor task. Behav. Brain Res. 2012, 232, 348-357. [CrossRef] [PubMed]

48. Roush, R.E. Dance, Dance Revolution: Change in Executive Function Following A Video Dance Intervention in Postmenopausal Women. Ph.D. Thesis, University of Pittsburgh, Pittsburgh, PA, USA, 2013.

49. Lorenz, R.C.; Gleich, T.; Gallinat, J.; Kühn, S. Video game training and the reward system. Front. Hum. Neurosci. 2015, 9, 40. [CrossRef] [PubMed]

50. West, G.L.; Zendel, B.R.; Konishi, K.; Benady-Chorney, J.; Bohbot, V.D.; Peretz, I.; Belleville, S. Playing Super Mario 64 increases hippocampal grey matter in older adults. PLoS ONE 2017, 12, e0187779. [CrossRef]

51. West, G.L.; Konishi, K.; Diarra, M.; Benady-Chorney, J.; Drisdelle, B.L.; Dahmani, L.; Sodums, D.J.; Lepore, F.; Jolicoeur, P.; Bohbot, V.D. Impact of video games on plasticity of the hippocampus. Mol. Psychiatry 2018, 23, 1566. [CrossRef] [PubMed]

52. DiPietro, J.A. Baby and The Brain: Advances in Child Development. Annu. Rev. Public Health 2000, 21, 455-471. [CrossRef] [PubMed]

53. Lenroot, R.K.; Giedd, J.N. Brain development in children and adolescents: Insights from anatomical magnetic resonance imaging. Neurosc. Biobehav. Rev. 2006, 30, 718-729. [CrossRef] [PubMed]

54. Blakemore, S.-J.; Choudhury, S. Development of the adolescent brain: Implications for executive function and social cognition. J. Child Psychol. Psychiatry 2006, 47, 296-312. [CrossRef] [PubMed]

55. Miguel-Hidalgo, J.J. Brain structural and functional changes in adolescents with psychiatric disorders. Int. J. Adolesc. Med. Health 2013, 25, 242-256. [CrossRef] [PubMed]

56. Tamnes, C.K.; Walhovd, K.B.; Torstveit, M.; Sells, V.T.; Fjell, A.M. Performance monitoring in children and adolescents: A review of developmental changes in the error-related negativity and brain maturation. Dev. Cognit. Neurosci. 2013, 6, 1-13. [CrossRef] [PubMed]

57. Vijayakumar, N.; Allen, N.B.; Youssef, G.; Dennison, M.; Yücel, M.; Simmons, J.G.; Whittle, S. Brain development during adolescence: A mixed-longitudinal investigation of cortical thickness, surface area, and volume: Brain Development During Adolescence. Hum. Brain Mapp. 2016, 37, 2027-2038. [CrossRef] [PubMed]

58. Arain, M.; Haque, M.; Johal, L.; Mathur, P.; Nel, W.; Rais, A.; Sandhu, R.; Sharma, S. Maturation of the adolescent brain. NDT 2013, 9, 449.

59. Peters, R. Ageing and the brain. Postgrad. Med. J. 2006, 82, 84-88. [CrossRef]

60. Persson, J.; Lustig, C.; Nelson, J.K.; Reuter-Lorenz, P.A. Age Differences in Deactivation: A Link to Cognitive Control? J. Cognit. Neurosci. 2007, 19, 1021-1032. [CrossRef]

61. Tulving, E.; Markowitsch, H.J. Episodic and declarative memory: Role of the hippocampus. Hippocampus 1998, 8, 198-204. [CrossRef] 
62. Barker, G.R.I.; Warburton, E.C. When Is the Hippocampus Involved in Recognition Memory? J. Neurosci. 2011, 31, 10721-10731. [CrossRef] [PubMed]

63. Hayter, A.L.; Langdon, D.W.; Ramnani, N. Cerebellar contributions to working memory. Neuroimage 2007, 36, 943-954. [CrossRef] [PubMed]

64. Erickson, K.I.; Voss, M.W.; Prakash, R.S.; Basak, C.; Szabo, A.; Chaddock, L.; Kim, J.S.; Heo, S.; Alves, H.; White, S.M.; et al. Exercise training increases size of hippocampus and improves memory. Proc. Nat. Acad. Sci. 2011, 108, 3017-3022. [CrossRef] [PubMed]

65. Jung, K.-I.; Park, M.-H.; Park, B.; Kim, S.-Y.; Kim, Y.O.; Kim, B.-N.; Park, S.; Song, C.-H. Cerebellar Gray Matter Volume, Executive Function, and Insomnia: Gender Differences in Adolescents. Sci. Rep. 2019, 9, 855. [CrossRef] [PubMed]

66. Garavan, H.; Kelley, D.; Rosen, A.; Rao, S.M.; Stein, E.A. Practice-related functional activation changes in a working memory task. Microsc. Res. Tech. 2000, 51, 54-63. [CrossRef]

67. Jansma, J.M.; Ramsey, N.F.; Slagter, H.A.; Kahn, R.S. Functional Anatomical Correlates of Controlled and Automatic Processing. J. Cognit. Neurosci. 2001, 13, 730-743. [CrossRef]

68. Milham, M.P.; Banich, M.T.; Claus, E.D.; Cohen, N.J. Practice-related effects demonstrate complementary roles of anterior cingulate and prefrontal cortices in attentional control. Neuroimage 2003, 18, 483-493. [CrossRef]

69. Landau, S.M.; Schumacher, E.H.; Garavan, H.; Druzgal, T.J.; D'Esposito, M. A functional MRI study of the influence of practice on component processes of working memory. Neuroimage 2004, 22, 211-221. [CrossRef]

70. Vartanian, O.; Jobidon, M.-E.; Bouak, F.; Nakashima, A.; Smith, I.; Lam, Q.; Cheung, B. Working memory training is associated with lower prefrontal cortex activation in a divergent thinking task. Neuroscience 2013, 236, 186-194. [CrossRef]

71. Arias-Carrión, O.; Stamelou, M.; Murillo-Rodríguez, E.; Menéndez-González, M.; Pöppel, E. Dopaminergic reward system: A short integrative review. Int. Arch. Med. 2010, 3, 24. [CrossRef]

72. Demirakca, T.; Cardinale, V.; Dehn, S.; Ruf, M.; Ende, G. The Exercising Brain: Changes in Functional Connectivity Induced by an Integrated Multimodal Cognitive and Whole-Body Coordination Training. Neural Plast. 2016, 2016. [CrossRef] [PubMed]

73. Chirles, T.J.; Reiter, K.; Weiss, L.R.; Alfini, A.J.; Nielson, K.A.; Smith, J.C. Exercise Training and Functional Connectivity Changes in Mild Cognitive Impairment and Healthy Elders. JAD 2017, 57, 845-856. [CrossRef] [PubMed]

74. Pessoa, L.; Adolphs, R. Emotion processing and the amygdala: From a "low road" to "many roads" of evaluating biological significance. Nat. Rev. Neurosci. 2010, 11, 773. [CrossRef] [PubMed]

75. Takeuchi, H.; Taki, Y.; Sassa, Y.; Hashizume, H.; Sekiguchi, A.; Fukushima, A.; Kawashima, R. Working Memory Training Using Mental Calculation Impacts Regional Gray Matter of the Frontal and Parietal Regions. PLoS ONE 2011, 6, e23175. [CrossRef] [PubMed]

76. Metzler-Baddeley, C.; Caeyenberghs, K.; Foley, S.; Jones, D.K. Task complexity and location specific changes of cortical thickness in executive and salience networks after working memory training. Neuroimage 2016, 130, 48-62. [CrossRef] [PubMed]

77. Hill, N.M.; Schneider, W. Brain Changes in the Development of Expertise: Neuroanatomical and Neurophysiological Evidence about Skill-Based Adaptations. In The Cambridge Handbook of Expertise and Expert Performance; Ericsson, K.A., Charness, N., Feltovich, P.J., Hoffman, R.R., Eds.; Cambridge University Press: Cambridge, UK, 2006; pp. 653-682, ISBN 978-0-511-81679-6.

78. Witte, A.V.; Savli, M.; Holik, A.; Kasper, S.; Lanzenberger, R. Regional sex differences in grey matter volume are associated with sex hormones in the young adult human brain. Neuroimage 2010, 49, 1205-1212. [CrossRef] [PubMed]

79. Yang, J. The influence of motor expertise on the brain activity of motor task performance: A meta-analysis of functional magnetic resonance imaging studies. Cogn. Affect Behav. Neurosci. 2015, 15, 381-394. [CrossRef]

80. Jang, H.; Lee, J.Y.; Lee, K.I.; Park, K.M. Are there differences in brain morphology according to handedness? Brain Behav. 2017, 7, e00730. [CrossRef]

81. Colloca, L.; Miller, F.G. Role of expectations in health. Curr. Opin. Psychiatry 2011, 24, 149-155. [CrossRef]

82. Shahar, E.; Shahar, D. Causal diagrams, the placebo effect, and the expectation effect. IJGM 2013, 6, 821. [CrossRef]

83. Brown, W.A. Expectation, the Placebo Effect and the Response to Treatment. R. I. Med. J. 2015, 98, 19. 
84. Cunningham, J.A.; Kypri, K.; McCambridge, J. Exploratory randomized controlled trial evaluating the impact of a waiting list control design. BMC Med. Res. Methodol. 2013, 13, 150. [CrossRef] [PubMed]

85. FDA Step 3: Clinical Research. Available online: https://www.fda.gov/forpatients/approvals/drugs/ ucm405622.htm (accessed on 29 May 2019).

86. Locke, H.S.; Braver, T.S. Motivational influences on cognitive control: Behavior, brain activation, and individual differences. Cogn. Affect. Behav. Neurosc. 2008, 8, 99-112. [CrossRef]

(C) 2019 by the authors. Licensee MDPI, Basel, Switzerland. This article is an open access article distributed under the terms and conditions of the Creative Commons Attribution (CC BY) license (http://creativecommons.org/licenses/by/4.0/). 